\title{
Limnological characteristics of lakes in the lowlands of Central Yakutia, Russia
}

\author{
Thomas KUMKE*, Marta KSENOFONTOVA ${ }^{1)}$, Luidmila PESTRYAKOVA ${ }^{1)}$, Larisa NAZAROVA ${ }^{2), 3)}$ and \\ Hans-Wolfgang HUBBERTEN ${ }^{3)}$ \\ Department of Statistics and Data Management, HMR London, Acton Lane, London, NW10 7NS, UK \\ ${ }^{1)}$ Water System Laboratory, Yakutsk State University, 58, Belinsky Street, Yakutsk, 677891, Russia \\ ${ }^{2)}$ Ecological Faculty, Kazan State University, 18, Kremlyovskaya, Kazan, 420008, Russia \\ ${ }^{3)}$ Alfred Wegener Institute for Polar and Marine Research, Research Department Potsdam, Telegrafenberg A43, 14473 Potsdam, \\ Germany \\ *e-mail corresponding author: tkumke@hmrlondon.com
}

\begin{abstract}
The physico-chemical characteristics of 47 lakes from two regions in the lowlands of Central Yakutia (Vilyuysk and Yakutsk), Eastern Siberia were analysed. The aims of this study were (i) to classify the lakes according to their ionic compositions and their nutrient concentrations, (ii) to quantify environmental gradients representing the main directions of variation in the measured variables, and (iii) to explore the relationship between the investigated lakes and their spatial positions. Most of the study lakes are shallow, thermokarst lakes that are slightly alkaline to alkaline. The lakes are predominantly oligotrophic, with some mesotrophic and a few eutrophic exceptions in the study region Vilyuysk. There are four hypertrophic lakes in the study region Yakutsk which are strongly affected by anthropogenic inputs and, in one case, additionally by inputs of water birds. Most part of the variance in the data is represented by major ion concentrations and related variables such as electrical conductivity. There were clear differences in these variables between the lakes of both study regions partly due to regional differences in the climate-induced, negative water balance (i.e. evaporation exceeds precipitation). The statistical analysis has shown that a significant part of the variance can be attributed to the type of vegetation in the lake's catchment (11\%), to the longitude (7.6\%) and to local spatial differences in the lake water chemistry (2.8\%). Hypothesis testing indicated that there are significant differences in the mean values of many variables according to vegetation type and to the region where the lakes are located. However, the hypothesis of spatial autocorrelation in the data had to be rejected. The results presented here have important implications for ongoing and future limnological and paleoenvironmental studies in Yakutia. The exploratory analysis has shown that the physico-chemical characteristics of Central Yakutian lakes are mainly influenced by vegetation and climate driven changes that provides the basis for paleoenvironmental studies.
\end{abstract}

Key words: Central Yakutia, Siberia, lakes, physico-chemical characteristics, alkaline lakes, salinity

\section{INTRODUCTION}

High latitude regions will be particularly affected by global climate change. For example, it has been shown that temperature changes are very pronounced in arctic and subarctic regions by both, predictions of General Circulation Models (e.g., Houghton et al. 1996; Watson \& Albritton 2001) and paleoecological data (e.g., Andreev \& Klimanov 2000; Fischer et al. 2004). Aquatic ecosystems are known to respond quickly and sensitively to such changes (e.g., Carpenter et al. 1992; Findlay et al. 2001; Smol 2002; Antoniades et al. 2005). Climate change will affect aquatic systems both directly and indirectly. Direct effects of warming include an increase in water temperature and evaporation whereas indirect effects include increased length of the ice-free season, the stability of lake water stratification, changes in the distribution of aquatic organisms, changes in catchment vegetation, increased fire frequency and increased depth of the active layer above the permafrost (e.g., Regier et al. 1990; Carpenter et al. 1992; Schindler et al. 1996; Rühland \& Smol 1998; Duff et al. 1999). Although the latter will affect the drainage regime and could locally increase the volume of surface waters, in general, the most important effect is a decrease in the water levels of lakes. Tracking past water level changes in subarctic regions is a major area of research in paleolimnology (e.g., Korhola et al. 2005). Decreasing water levels will also alter the chemical composition of lake water, for example by increasing of the major cation concentration (e.g., Wolin \& Duthie 1999). This indirect effect is especially dramatic in regions with continental climates such as in Central and Eastern Siberia.

The Republic of Yakutia is located in the eastern part of Siberia (between approximately $57^{\circ}$ and $75^{\circ} \mathrm{N}$ and between $110^{\circ}$ and $160^{\circ} \mathrm{E}$ ). Yakutia is a relatively expansive region that is about five times larger than the area of France. Although Yakutia is very sparsely populated (about 0.3 inhabitants per $\mathrm{km}^{2}$ ), the central part in the proximity of the rivers Lena and Vilyuy is urbanized and cultivated. Lakes are numerous throughout the region ( $c a 700,000)$ and in the central part, there are approximately 106,000 lakes. The lakes in Central Yakutia cover an area of $c a$ one million hectares and have a volume of more than 180 billion $\mathrm{m}^{3}$ (Ksenofontova et al. 2005). Most of the lakes are originated 
through thermokarst processes and are therefore relatively shallow (i.e. between $1 \mathrm{~m}$ and $5 \mathrm{~m}$ water depth). Due to the characteristic continental climate of Central Yakutia, the lakes are subjected to changing water levels and desiccation. They are sensitive to any variations in climate, vegetation or anthropogenic influence. Since many of the lakes, at least in the urban areas, are used by man, data about the physico-chemical properties of the lake water and the lake's biota are urgently needed. Unfortunately, such data are rare in Central Yakutia and other regions of Siberia (e.g., Anisimova 1959, 1973, 1978; Duff et al. 1999; Anisimova et al. 2005). This is mainly the result of the vast distances between study lakes as well as difficulties in getting access to these sites. For example, in the study by Duff et al. (1999) field work was carried out in three different regions of Siberia over three consecutive years within a three week period in July. Access to these lakes was facilitated by helicopter only. As with most studies of this kind in remote regions, this limnological survey was limited to a one-time collection of data from each lake and resulted in three clusters of sampling sites that were separated by more than $1000 \mathrm{~km}$. Data from single limnological measurements and discontinuous sampling transects affect the representativity of the variables measured and especially the latter one affects the search for major water chemistry gradients in paleoenvironmental studies (e.g., Birks 1998; Kumke et al. 2004). However, if the lakes under study are sampled in a relatively short time period during one season (e.g., two weeks in July), the problem of representativity caused by one-time measurements might be reduced.

The knowledge of the physico-chemical properties of lake water is very important in quantitative paleolimnological reconstructions (e.g., Rühland \& Smol 1998; Bennion \& Smith 2000; Smol 2002; Korhola et al. 2005). The aim in such studies is to develop an empirical model based on the relationships between aquatic organisms (e.g., diatoms, chironomids, etc.) and abiotic variables (e.g., water chemistry, climate variables, etc.), particularly in terms of species optima to a measured variable. This inference model can then be used to reconstruct past changes of the abiotic variable of interest. To obtain empirical models (i.e. transfer functions), a calibration dataset is needed which consists of the water chemistry data, climatological data and the species distributions from about 50 to 100 lakes (for a review see Birks 1995, 1998). Since the transfer function estimates a single variable of the physico-chemical characteristics measured in the calibration dataset, it is important to choose a sampling frequency appropriate for obtaining reliable estimates of the variable to be reconstructed (e.g., Rühland \& Smol 1998; Bennion \& Smith 2000; Rühland et al. 2003). This differs from variable to variable, for example in temperate regions, the annual variability of $\mathrm{pH}$ is much lower than that of nutrients (e.g., Bennion \& Smith 2000).
The purpose of our research in Yakutia is twofold: we want to establish a calibration dataset for paleoenvironmental reconstructions using aquatic organisms and to create a data base for limnological variables and the distributions of aquatic organisms in Yakutian lakes. The aims of this paper are (i) to explore the results of physico-chemical characteristics in 47 lakes in Central Yakutia, (ii) to classify the lakes according to their major limnological gradients and (iii) to analyze the spatial variation of the physico-chemical characteristics of the lake water. The results of these analyses are of major importance for limnologists since very few limnological data of this vast region exist. Northern regions are very sensitive to climatic as well as environmental changes and limnological studies are of great interest for the paleolimnological community, as their results can be used for quantitative palaeoecological reconstructions, up to now seriously lacking in Northern Russia.

\section{MATERIAL AND METHODS}

\subsection{Study sites}

During the summers 2003 and 2004, a total of 47 lakes were sampled in two regions in the Central Yakutian lowlands (Fig. 1). The Central Yakutian lowlands are bounded by the Prelenskoe Plateau to the south and the Verkhoyansk Range to the north (Pewe \& Journaux 1983). The study region Vilyuysk (I) is located close to the river Vilyui. During this sampling campaign in July 2003, 30 lakes were studied in eight different subregions (PG1700 to PG1729 in Tab. 1). The second study region, Yakutsk (II) is located close to the River Lena. The field work there consisted of sampling 17 lakes in two different subregions (PG1730 to PG1746 in Tab. 1) west and northeast of the city of Yakutsk during the first two weeks in July 2004.

According to Gavrilova (1973), the observed longterm climate is similar in both regions with minimum air temperatures in January of $-61{ }^{\circ} \mathrm{C}$ and $-63{ }^{\circ} \mathrm{C}$, maximum air temperatures in July of $37{ }^{\circ} \mathrm{C}$ and $38^{\circ} \mathrm{C}$ and annual precipitation of $243 \mathrm{~mm}$ and $203 \mathrm{~mm}$ in Vilyuysk and Yakutsk, respectively. The mean annual number of days of freezing temperatures is 205 (Gavrilova 1973). The annual evaporation is approximately $350 \mathrm{~mm}$ to $400 \mathrm{~mm}$ in both regions. Thus, there is a moisture deficit of 100 to $150 \mathrm{~mm} \mathrm{y}^{-1}$ in the region around Vilyuysk and 150 to $200 \mathrm{~mm} \mathrm{y}^{-1}$ in the region around Yakutsk. The lakes are frozen for most of the year with an ice-free period up to $120 \mathrm{~d} \mathrm{y}^{-1}$.

The area around Vilyuysk (I) is underlain by Mesozoic rocks whereas the study region around Yakutsk (II) is underlain by Cenozoic rocks in the north and Mesozoic rocks in the Central part and in the south. Most of the sampling lakes of the Yakutsk region are located east of the River Lena (region 10 in Tab. 1) close to the Tyungyulyu terrace which is covered by well-sorted silt and characterized by ice-wedge and thermokarst topography (Pewe \& Journaux 1983). 


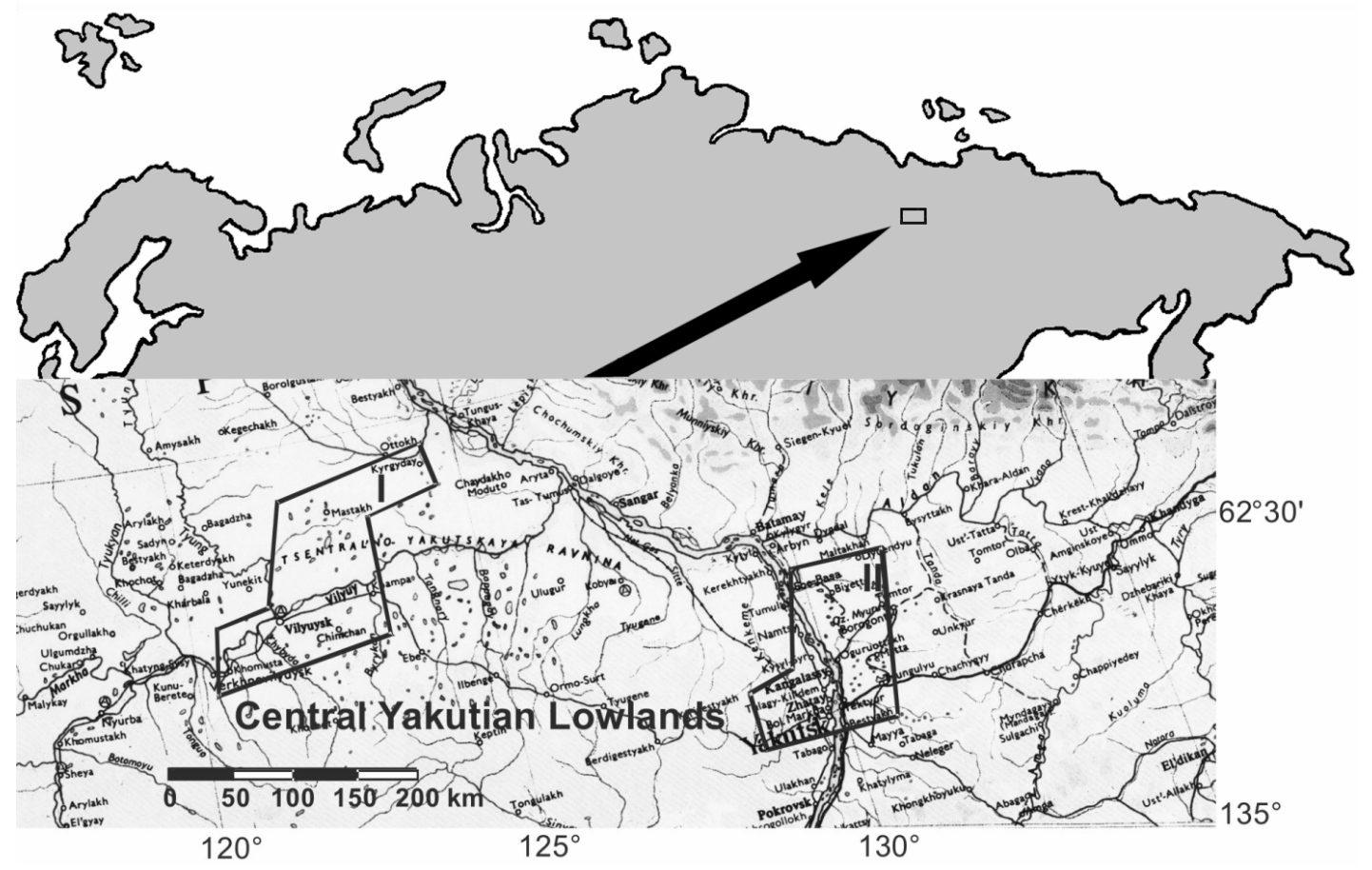

Fig. 1. Geographical map of Central Yakutia with the study regions I and II.

Although it is still controversial, most areas of Central Yakutia were probably not glaciated during the Middle and Late Pleistocene. However, the main rivers drained into glaciated areas resulting in glacial outwash of sediment into the wide valleys of the lowlands (Pewe \& Journaux 1983). Both study regions are underlain by continuous permafrost with an active layer thickness up to $70 \mathrm{~cm}$ depth. In general, the thickness of permafrost in Central Yakutia is between $300 \mathrm{~m}$ and $500 \mathrm{~m}$ (Akademiya Nauk 1989).

Both study regions are located within the Boreal coniferous forest zone. The vegetation is dominated by Taiga trees (see also Tahtadzhan 1978) such as larch (e.g., Larix dahurica), pine (e.g., Pinus sylvestris) and birch trees (e.g., Betula pendula). The catchments of the study lakes were often covered by forest vegetation or were used for pasture and partly agriculture.

\subsection{Field sampling and measurements}

Lakes chosen for sampling had a simple morphology and a single lake basin. From each study lake, we took water samples, surface sediment samples, phytoplankton and periphyton samples as well as some short lake sediment cores. The water samples were taken from the deepest part of the lake. The sampling took place from a rubber boat with a water sampler about $50 \mathrm{~cm}$ beneath the water surface. The water depths were measured frequently using an echolot. Beside the water depth, the water transparency was determined using a Secchi disk with a diameter of $20 \mathrm{~cm}$. Water temperature, dissolved oxygen, electrical conductivity (at $25^{\circ} \mathrm{C}$ ) and $\mathrm{pH}$ were measured using a thermometer and electrodes (WTW and Hanna instruments), respectively. All electrodes were calibrated frequently during the field work. From the lakes deeper than $5 \mathrm{~m}$, water samples near the lake bottom were additionally collected and the temperature and dissolved oxygen were measured. To determine the thermal stratification of the water bodies, depth profiles of the water temperature were taken to estimate the thermocline. A field test kit was used to obtain a first estimate of nitrate $\left(\mathrm{NO}_{3}\right)$, nitrite $\left(\mathrm{NO}_{2}\right)$, ammonium $\left(\mathrm{NH}_{4}\right)$ and phosphate $\left(\mathrm{PO}_{4}\right)$. The water samples for total element concentrations and anion analysis were filtered through cellulose acetate filters with a pore size of 0.45 $\mu \mathrm{m} .200 \mu \mathrm{l}$ of $\mathrm{HNO}_{3}$ were added to the samples for total element concentrations analyses for conservation purposes. All samples were stored in a thermobox to ensure cool conditions.

The concentrations of anions, such as of bromide $(\mathrm{Br})$, chloride $(\mathrm{Cl})$, flouride $(\mathrm{F}), \mathrm{NO}_{3}$ and $\mathrm{NO}_{2}$ were measured using ion chromatography (Dionex, detection limits: $0.05-0.1 \mathrm{mg} \mathrm{L}^{-1}$ ). The concentrations of $\mathrm{PO}_{4}$ were determined photometrically (Wetzel \& Likens 1991; detection limit: $\left.1 \mu \mathrm{g} \mathrm{L}^{-1}\right)$. The total concentrations of aluminum ( $\mathrm{Al})$, barium $(\mathrm{Ba})$, calcium $(\mathrm{Ca})$, iron $(\mathrm{Fe})$, potassium $(\mathrm{K})$, magnesium $(\mathrm{Mg})$, manganese $(\mathrm{Mn})$, sodium $(\mathrm{Na})$, phosphorus $(\mathrm{P})$, silicon $(\mathrm{Si})$ and strontium (Sr) were determined using an Inductivity Coupled Plasma Optical Emission Spectrometer (ICP-OES, detection limits: $\left.20 \mu \mathrm{g} \mathrm{L}^{-1}-0.2 \mathrm{mg} \mathrm{L}^{-1}\right)$. To ensure the quality of the analytical methods and to check the plausibility of the data, the ion balance of each sample was calculated, resulting in deviations of about $\pm 5 \%$ for 
Tab. 1. Lake Names and main geographical characteristics of the study sites in Central Yakutia.

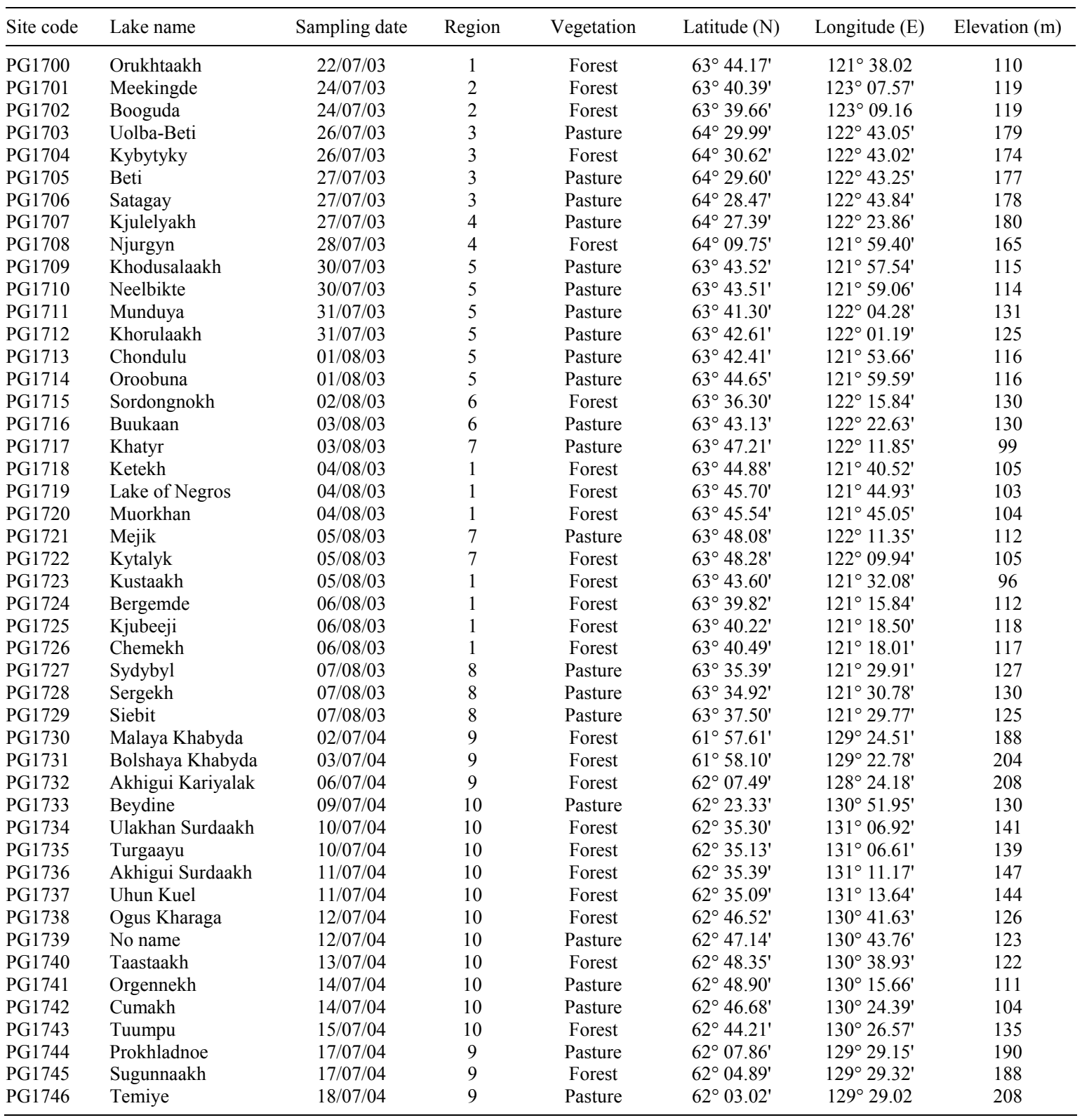

most of the samples. To determine the concentrations of dissolved organic carbon (DOC), water samples were filtered through pre-ignited glass microfibre Whatman filters. The filtrates were analysed using an element analyzer HighTOC (Elementar Analysensysteme $\mathrm{GmbH}$, detection limits: $1.0 \mathrm{mg} \mathrm{L}^{-1}$ ) by evaporating the samples at $950{ }^{\circ} \mathrm{C}$ and measuring the carbon dioxide with infra-red detection. The total inorganic carbon (TIC) was also determined with the HighTOC element analyser. The unfiltered samples were pre-acidified down to $\mathrm{pH}<2.0$ which transfers all the carbonates into carbon dioxide, and then measured by the infra-red detector. In total, 24 physico-chemical characteristics of the lakes were measured.

\subsection{Statistical analyses}

Prior to statistical analyses, all variables (with exception of $\mathrm{pH}$ ) were transformed when their distributions were highly skewed using log transformation (e.g., Webster \& Oliver 2000). Variables that contained site values below the detection limit were replaced by the value of the detection limit.

To explore the relationships between the measured variables, a correlation matrix was calculated. To account for non-normality of the data, Spearman's rank correlation coefficient was used (Legendre \& Legendre 1998). To test several hypotheses of differences in the means and variances of the variables, Analysis of Vari- 
Tab. 2. Statistical summary of the limnological measurements of the study lakes in Central Yakutia. The abbreviations SD and CV refer to the standard deviation and coefficient of variation, respectively. The symbol * indicates median values at the detection limit of the measured variable.

\begin{tabular}{|c|c|c|c|c|c|c|}
\hline Variable & $\mathrm{n}$ & Mean & Median & SD & Skew & CV (\%) \\
\hline $\mathrm{z}_{\mathrm{water}}(\mathrm{m})$ & 47 & 3.74 & 1.80 & 7.9 & 5.5 & 212 \\
\hline $\mathrm{Z}_{\text {Secchi }}(\mathrm{m})$ & 44 & 1.05 & 0.80 & 0.9 & 2.2 & 86 \\
\hline $\mathrm{T}_{\text {water }}\left({ }^{\circ} \mathrm{C}\right)$ & 47 & 22.90 & 22.60 & 3.1 & 0.5 & 13 \\
\hline Cond $\left(\mu \mathrm{S} \mathrm{cm}^{-1}\right)$ & 47 & 464.00 & 269.00 & 731.0 & 3.3 & 158 \\
\hline $\mathrm{pH}$ & 47 & 8.48 & 8.45 & 0.5 & 0.5 & 6 \\
\hline $\mathrm{O}_{2}\left(\mathrm{mg} \mathrm{L}^{-1}\right)$ & 31 & 7.2 & 6.8 & 3.1 & 0.9 & 43 \\
\hline $\operatorname{DOC}\left(\mathrm{mg} \mathrm{L}^{-1}\right)$ & 41 & 21.46 & 19.53 & 11.3 & 0.4 & 53 \\
\hline $\mathrm{TIC}\left(\mathrm{mg} \mathrm{L}^{-1}\right)$ & 37 & 61.09 & 31.58 & 94.2 & 2.8 & 154 \\
\hline $\mathrm{F}\left(\mathrm{mg} \mathrm{L}^{-1}\right)$ & 47 & 0.26 & 0.16 & 0.3 & 3.4 & 115 \\
\hline $\mathrm{Cl}\left(\mathrm{mg} \mathrm{L}^{-1}\right)$ & 47 & 18.63 & 2.55 & 52.5 & 3.5 & 281 \\
\hline $\mathrm{SO}_{4}\left(\mathrm{mg} \mathrm{L}^{-1}\right)$ & 47 & 9.02 & 0.16 & 54.8 & 6.9 & 607 \\
\hline $\mathrm{Br}\left(\mu \mathrm{g} \mathrm{L}^{-1}\right)$ & 47 & 141.50 & 60.00 & 246.8 & 3.7 & 174 \\
\hline $\mathrm{NO}_{3}\left(\mu \mathrm{g} \mathrm{L}^{-1}\right)$ & 47 & 2401.10 & 150.00 & 628.0 & 3.6 & 262 \\
\hline $\mathrm{NH}_{4}\left(\mu \mathrm{g} \mathrm{L}^{-1}\right)$ & 47 & 209.10 & 160.00 & 168.7 & 1.5 & 81 \\
\hline $\mathrm{NO}_{2}\left(\mu \mathrm{g} \mathrm{L}^{-1}\right)$ & 47 & 96.90 & 7.80 & 267.7 & 3.4 & 275 \\
\hline $\mathrm{PO}_{4}\left(\mu \mathrm{g} \mathrm{L}^{-1}\right)$ & 47 & 166.90 & $1.00 *$ & 691.8 & 5.2 & 415 \\
\hline $\mathrm{Al}\left(\mu \mathrm{g} \mathrm{L}^{-1}\right)$ & 47 & 31.90 & 21.80 & 26.3 & 4.3 & 82 \\
\hline $\mathrm{Ba}\left(\mu \mathrm{g} \mathrm{L}^{-1}\right)$ & 47 & 31.50 & 20.00 & 26.9 & 3.7 & 85 \\
\hline $\mathrm{Ca}\left(\mathrm{mg} \mathrm{L}^{-1}\right)$ & 47 & 19.27 & 17.14 & 11.3 & 0.7 & 59 \\
\hline $\mathrm{Fe}\left(\mu \mathrm{g} \mathrm{L}^{-1}\right)$ & 47 & 88.40 & 63.40 & 79.4 & 1.6 & 90 \\
\hline $\mathrm{K}\left(\mathrm{mg} \mathrm{L}^{-1}\right)$ & 47 & 8.78 & 3.26 & 18.5 & 3.5 & 211 \\
\hline $\operatorname{Mg}\left(\mathrm{mg} \mathrm{L}^{-1}\right)$ & 47 & 33.59 & 12.33 & 64.7 & 3.3 & 193 \\
\hline $\mathrm{Na}\left(\mathrm{mg} \mathrm{L}^{-1}\right)$ & 47 & 50.53 & 11.27 & 133.8 & 3.6 & 265 \\
\hline $\mathrm{Si}\left(\mathrm{mg} \mathrm{L}^{-1}\right)$ & 47 & 3.51 & 1.80 & 3.4 & 1.0 & 96 \\
\hline $\operatorname{Sr}\left(\mu \mathrm{g} \mathrm{L}^{-1}\right)$ & 47 & 165.80 & 154.20 & 119.8 & 3.6 & 72 \\
\hline
\end{tabular}

ance (ANOVA) was performed with the data. To test the homogeneity of variances, Hartley's $F_{\text {max }}$-test, Cochrans $C$-test and Bartlett's $\gamma^{2}$-test were used. Tests of differences in the mean were conducted with MannWhitney's $U$-test which is a non-parametric test and suitable when the data are non-normally distributed (Sokal \& Rohlf 1995). The hypothesis of associations between the variables and the spatial coordinates was tested using a standardized Manteltest with the Euclidean distance as a measure of dissimilarity among the lake sites. In standardized Manteltests, the distance coefficients of the sites based on the physico-chemical variables are correlated with those distance coefficients based on the spatial coordinates (Legendre \& Legendre 1998). Additionally, a variogram analysis of the principal components of the variables was conducted to explore their spatial structure (see Kumke et al. 2005).

To classify the lakes according to their physicochemical properties, cluster analysis was performed. The cluster analysis was carried out using the Ward method (Legendre \& Legendre 1998). To test the variables for interactions with possible gradients, a nonparametric variant of discriminant analysis (MRPP) and redundancy analysis (RDA) were carried out. Redundancy analysis is a canonical ordination technique which aims to explain the variability of the water chemistry data by independent gradients. It consists of a multiple linear regression of the gradients on the water chemisty data followed by eigenanalysis of the resulting fits of the variables (for details of the method see Legendre \& Legendre 1998). The calculation of eigenvectors and eigenvalues is carried out by maximizing the variance of the data (i.e. the first principal axis represents most of the data variance). As gradients, we defined Vegetation, Land use and Subregion (i.e. the partitioning of the sites into 10 geographically different areas according to Tab. 1) as categorical variables. The geographical coordinates were represented as X-coordinate (i.e. east-west) and Y-coordinate (i.e. north-south).

All calculations were carried out using the software STATISTICA 5.5 (StatSoft, Inc. 1999) for summary and test statistics, PCORD 4.0 (McCune \& Mefford 1999) for cluster analysis, Manteltest and MRPP, CANOCO for Windows 4.5 (ter Braak \& Šmilauer 2002) for RDA, and GEOEAS 1.2.1 (Englund \& Sparks 1991) for variogram analysis.

\section{RESULTS}

\subsection{Summary of the physico-chemical characteristics}

Most of the study lakes were shallow with a median water depth of $1.80 \mathrm{~m}$ (Tab. 2). There were some exceptions, among them Lake Sordongnokh (study area I) with a measured water depth of $52.6 \mathrm{~m}$. Apart from that lake, all other lakes likely originated through thermokarst processes after the Last Glaciation. There was a substantial variation in the Secchi depths of the lakes as calculated by the coefficient of variation $(\mathrm{CV}=86 \%)$. The median Secchi depth was about $50 \%$ of the median water depth. The Secchi depths of three lakes were excluded from the statistical analysis; since water and Secchi depths were the same (i.e., the lake bottom was visible). Lakes with poor transparency had most often a yellowish to light brownish colour, indicating resuspen- 
(a)

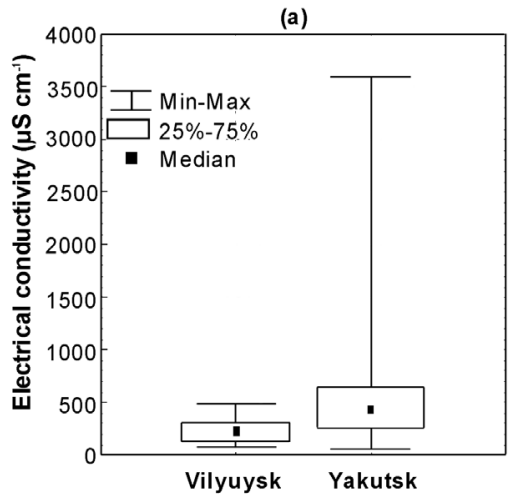

(c)

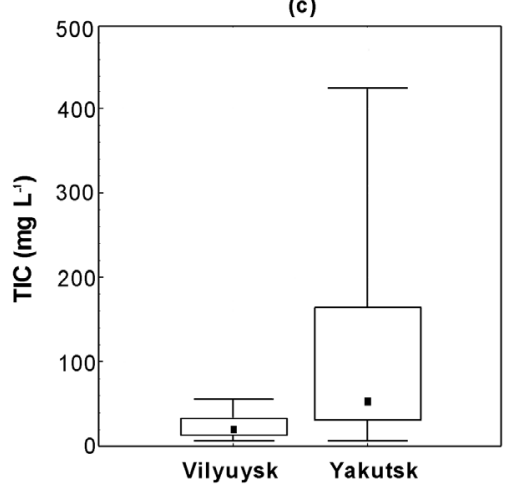

(b)

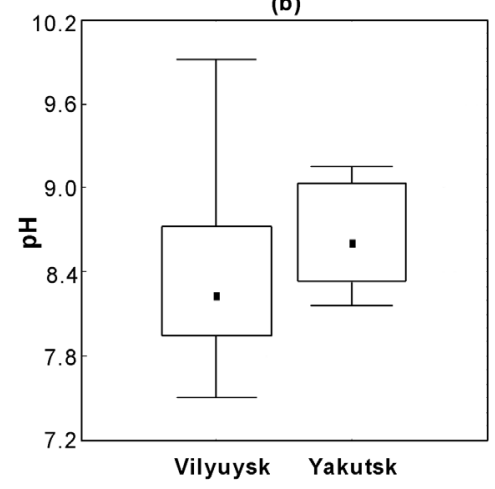

(d)

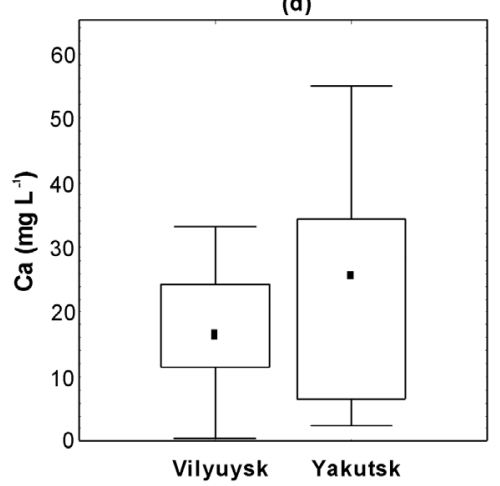

Fig. 2. Box-Whisker plots for selected physico-chemical characteristics of the lakes in Central Yakutia. The Box-Whisker plots are categorized according to the study regions Vilyuysk and Yakutsk.

sion of sediments or the presence of humic substances in solution. The bottoms of many lakes were covered by submerged macrophytes. All study lakes had wellmixed water bodies and were not stratified at the time of sampling except for the Lake Taastaakh (study area II). Lake Taastaakh was a small oval lake with maximum water depth of $17.1 \mathrm{~m}$. A measured profile of water temperature indicated a thermocline between 4 and $6 \mathrm{~m}$ water depth.

All lakes were slightly alkaline with median $\mathrm{pH}$ of ca 8.5 and a very low variability $(\mathrm{CV}=6 \%)$, and well oxygenated (Tab. 2). The variability of concentrations of major cations, anions, electrical conductivity and TIC were quite high with particularly large values in the lakes of study area II. This resulted in highly skewed distributions for these variables. The concentrations of nutrients (i.e. $\mathrm{PO}_{4}$ and $\mathrm{NO}_{3}$ ) were generally low. Assuming that $\mathrm{PO}_{4}$ is representative for the total phosphorus in these lakes, most of them within study area I (i.e. region Vilyuysk) were oligotrophic (i.e. TP $<10 \mu \mathrm{g}$ $\mathrm{L}^{-1}$ ) and only some were mesotrophic (i.e. $\mathrm{TP}=10-35$ $\mu \mathrm{g} \mathrm{L}^{-1}$ ) or eutrophic (i.e. $\mathrm{TP}=35-100 \mu \mathrm{g} \mathrm{L}^{-1}$ ) according to Vollenweider \& Kerekes (1982). However, there were a few exceptions in study area II with nutrient concentrations well in the range of hypertrophic (i.e. TP $>100 \mu \mathrm{g} \mathrm{L}^{-1}$ ) conditions. The analytical results of $\mathrm{PO}_{4}$ and $\mathrm{NO}_{3}$ confirmed the field test results.
The Spearman rank correlation coefficients (not shown) between the variables show high significant positive correlations $(p \leq 0.05)$ between electrical conductivity and TIC ( $r=0.98)$, as well as the major cations and anions, except for $\mathrm{Ca}$. Moreover, major cations and anions are in most cases significantly interrelated. Dissolved organic carbon concentrations are significantly and positively correlated with $\mathrm{pH}(r=0.60)$ and negatively correlated with Secchi depth $(r=-0.55)$.

\subsection{Classification of central Yakutian lakes}

To examine regional differences in the physicochemical lake properties, selected regional Box-Whisker plots (Fig. 2) and the results of ANOVAs (Tab. 3) are presented. The Box-Whisker plots represent the general tendency that many of the measured variables in the Yakutsk (II) study area vary to a larger degree than in the Vilyuysk (I) study area. This is evident from the ranges of electrical conductivity (Fig. 2a), TIC (Fig. 2c) and $\mathrm{Ca}$ (Fig. 2d). The pH-values (Fig. 2b) are an exception, as well as $\mathrm{O}_{2}$, DOC and water depth. The larger variability in water depth in the Vilyuysk (I) study area is likely due to the exceptional depth of Lake Sordongnokh. An interesting feature of the Box-Whisker plots is the distinct regional right-skewed appearance of some variables in the region Yakutsk, for example electrical conductivity and TIC (Fig. 2). 
Tab. 3. Comparison of differences in the mean between the sites of the regions Vilyuysk $(\mathrm{n}=30)$ and Yakutsk $(\mathrm{n}=17)$ and between the sites with different vegetation $\left(n_{\text {Forest }}=25 ; n_{\text {Pasture }}=22\right)$ using Mann-Whitney's $U$-test and results for the test of homogeneity of variances $\left(F_{\max }\right.$-test). The test results are given as probabilities. Probabilities in bold indicate significant differences in the means and the rejection of the hypothesis of homogeneity of variance. $* n_{\mathrm{Vilyusk}}=14$; $n_{\text {Pasture }}=14 ; n_{\text {Forest }}=24 ; * * n_{\text {Yakutsk }}=11 ; n_{\text {Pasture }}=18 ; n_{\text {Forest }}=23: * * * n_{\text {Vilyuysk }}=19$; $n_{\text {Pasture }}=16 ; n_{\text {Forest }}=20$

\begin{tabular}{|c|c|c|c|c|}
\hline \multirow[b]{2}{*}{ Variable } & \multicolumn{2}{|c|}{ Region } & \multicolumn{2}{|c|}{ Vegetation } \\
\hline & $U$-test & $F_{\max }$-test & $U$-test & $F_{\max }$-test \\
\hline $\mathrm{Z}_{\text {water }}(\mathrm{m})$ & 0.30 & 0.007 & 0.35 & 0.001 \\
\hline $\mathrm{Z}_{\text {Secchi }}(\mathrm{m})$ & 0.84 & 0.003 & 0.87 & 0.36 \\
\hline Cond $\left(\mu \mathrm{S} \mathrm{cm}^{-1}\right)$ & 0.01 & 0.001 & 0.001 & 0.001 \\
\hline $\mathrm{pH}$ & 0.02 & 0.03 & 0.22 & 0.83 \\
\hline $\mathrm{O}_{2}\left(\mathrm{mg} \mathrm{L}^{-1}\right)^{*}$ & 0.93 & 0.001 & 0.02 & 0.001 \\
\hline $\mathrm{DOC}\left(\mathrm{mg} \mathrm{L}^{-1}\right)^{* *}$ & 0.01 & 0.41 & 0.32 & 0.54 \\
\hline $\operatorname{TIC}\left(\mathrm{mg} \mathrm{L}^{-1}\right)^{* * *}$ & 0.001 & 0.001 & 0.01 & 0.001 \\
\hline $\mathrm{F}\left(\mathrm{mg} \mathrm{L}^{-1}\right)$ & 0.001 & 0.001 & 0.03 & 0.29 \\
\hline $\mathrm{Cl}\left(\mathrm{mg} \mathrm{L}^{-1}\right)$ & 0.001 & 0.001 & 0.001 & 0.001 \\
\hline $\mathrm{SO}_{4}\left(\mathrm{mg} \mathrm{L}^{-1}\right)$ & 0.23 & 0.001 & 0.14 & 0.001 \\
\hline $\operatorname{Br}\left(\mu \mathrm{g} \mathrm{L}^{-1}\right)$ & 0.001 & 0.001 & 0.03 & 0.001 \\
\hline $\mathrm{NO}_{3}\left(\mu \mathrm{g} \mathrm{L}^{-1}\right)$ & 0.01 & 0.60 & 0.66 & 0.81 \\
\hline $\mathrm{NH}_{4}\left(\mu \mathrm{g} \mathrm{L}^{-1}\right)$ & 0.14 & 0.001 & 0.07 & 0.001 \\
\hline $\mathrm{NO}_{2}\left(\mu \mathrm{g} \mathrm{L}^{-1}\right)$ & 0.01 & 0.52 & 0.13 & 0.001 \\
\hline $\mathrm{PO}_{4}\left(\mu \mathrm{g} \mathrm{L}^{-1}\right)$ & 0.49 & 0.001 & 0.17 & 0.001 \\
\hline $\mathrm{Al}\left(\mu \mathrm{g} \mathrm{L}^{-1}\right)$ & 0.02 & 0.001 & 0.60 & 0.001 \\
\hline $\mathrm{Ba}\left(\mu \mathrm{g} \mathrm{L}^{-1}\right)$ & 0.04 & 0.001 & 0.17 & 0.001 \\
\hline $\mathrm{Ca}\left(\mathrm{mg} \mathrm{L}^{-1}\right)$ & 0.18 & 0.001 & 0.04 & 0.98 \\
\hline $\mathrm{Fe}\left(\mu \mathrm{g} \mathrm{L}^{-1}\right)$ & 0.09 & 0.64 & 0.03 & 0.04 \\
\hline $\mathrm{K}\left(\mathrm{mg} \mathrm{L}^{-1}\right)$ & 0.001 & 0.001 & 0.001 & 0.001 \\
\hline $\operatorname{Mg}\left(\mathrm{mg} \mathrm{L}^{-1}\right)$ & 0.01 & 0.001 & 0.001 & 0.001 \\
\hline $\mathrm{Na}\left(\mathrm{mg} \mathrm{L}^{-1}\right)$ & 0.001 & 0.001 & 0.001 & 0.001 \\
\hline $\mathrm{Si}\left(\mathrm{mg} \mathrm{L}^{-1}\right)$ & 0.01 & 0.28 & 0.40 & 0.001 \\
\hline $\operatorname{Sr}\left(\mu \mathrm{g} \mathrm{L}^{-1}\right)$ & 0.59 & 0.001 & 0.001 & 0.02 \\
\hline
\end{tabular}

The results of the cluster analysis indicate a classification consisting of seven different associations of lakes according to their different catchment vegetation, physico-chemical characteristics and geological settings. The dendrogram (Fig. 3) shows these seven classes, whereas $80 \%$ of the variability still remains. Cluster I consists of shallow lakes from forested areas that had low electrical conductivity (i.e. from $c a 50$ to $100 \mu \mathrm{S} \mathrm{cm}^{-1}$ ) low concentrations of TIC, and low concentrations of major cations and anions. Except for one lake, Cluster II consists of lakes situated at pastured sites. These lakes are characterized by moderate electrical conductivity (i.e. from $\mathrm{ca} 300$ to $400 \mu \mathrm{S} \mathrm{cm} \mathrm{cm}^{-1}$ ) and moderate concentrations of TIC, major cations and anions. Cluster III also consists of lakes from pastured sites with one exception. These lakes also had moderate conductivity and ionic concentrations. The main differences between these pasture lakes to those ones in Cluster II are their relatively high observed $\mathrm{pH}$ values (i.e. above 9.0). It should be noted that these differences reflect the conditions at the time when the lakes were sampled and they might be affected by, for example, differences in the intensity of phytoplankton activity. Cluster IV mainly consists of lakes from forest sites that are geographically close together with two exceptions. These lakes had low electrical conductivity and ionic concentrations and unlike lakes from Cluster I, relatively low $\mathrm{pH}$ val- ues (7.7 to 8.0). Cluster $\mathrm{V}$ groups together lakes with moderate electrical conductivity and moderate to slightly higher concentrations of major cations and anions. The main difference between these lakes and those of clusters II and III is their low transparency. Cluster VI consists of lakes with relatively high electrical conductivity (i.e. from $c a 450$ to $600 \mu \mathrm{S} \mathrm{cm}^{-1}$ ) and higher concentrations of TIC and major cations and anions. Lakes grouped into cluster VII had very high electrical conductivities (i.e. $>1500 \mu \mathrm{S} \mathrm{cm}^{-1}$ ), high concentrations of TIC, nitrate, partly phosphate, major cations and anions.

Three lakes could not be classified. The water chemistry of Lake Njurgyn (PG1708) was very different from all other lakes (i.e. measured concentrations of all characteristics were distinctly lower). This is likely due to the distinctly different geological setting and origin of Lake Njurgyn surrounded by sand dune formations. Lake Prokhladnoe (PG1744) could not be clustered due to its very high concentration of sulphate which is likely to be originated by geological formation in the surroundings of the lake (Ksenofontova et al. 2005). Lake Sordongnokh (PG1715) could be not classified due to its different morphometrical properties (i.e. the maximum water depth of $>50 \mathrm{~m}$ ).

From the dendrogram (Fig. 3), it is evident that, to some degree, lakes are grouped together according to 


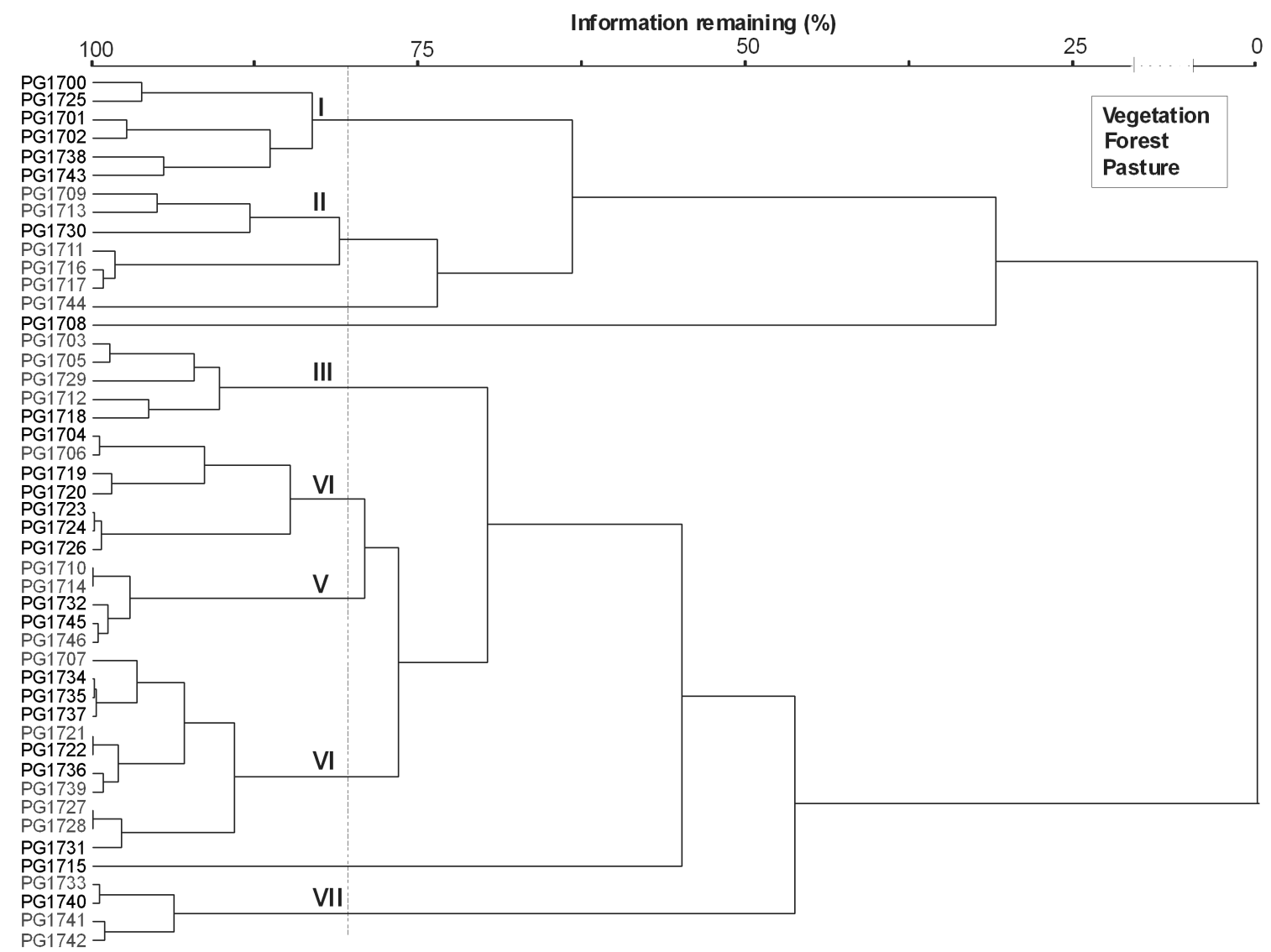

Fig. 3. Dendrogram of a cluster analysis using the Ward method. The vertical line represents the cut-off criterium for cluster partitioning. The Roman numbers are the numbers of cluster.

the vegetation of their surroundings. Differences in the geological settings of the catchments did not contribute to the lake classification, but inhibited classification of two individual lakes (Lake Njurgyn and Lake Prokhladnoe). To analyze the effect of vegetation on the lake water chemistry, MRPP and ANOVAs were conducted to test differences in the means between forested and pastured sites. The results of the MRPP indicate that mean similarities, measured by the Euclidean distance, within the groups (i.e. forest sites and pastured sites) were significantly different $(p=0.02)$. The chemical characteristics of the lakes surrounded by forests are much more homogeneous than those of lakes surrounded by pasture. The results of the ANOVAs (Tab. 3 ) show that 12 of 24 measured variables have significantly different mean values when forest and pasture sites are compared using Mann-Whitney's U-test. All variables are significantly higher in lakes at pastured sites, including electrical conductivity, TIC, $\mathrm{Cl}$ and the major cations $\mathrm{Ca}, \mathrm{Mg}, \mathrm{K}$ and $\mathrm{Na}$.

Figure 4 presents the Box-Whisker plots of the variables $\mathrm{Na}, \mathrm{Cl}, \mathrm{Mg}$ and $\mathrm{K}$ according to the vegetation group. All quartiles and medians are distinctly higher in the lakes surrounded by pasture. The greatest differences are the maximum values and the skew of the dis- tributions, which at the pastured sites are much higher than at the forest sites. The four variables chosen for the Box-Whisker plot contribute to a large extent to the variance of all variables.

To analyze which factors independently and significantly contribute to the variability in the water chemical characteristics, a RDA and partial RDA was performed. Prior to the constrained ordination, an unconstrained ordination (PCA) was performed to compare the unconstrained variation patterns with those extracted using explanatory variables. Figure 5 shows the scatter plots of the ordinated sampling sites (Fig. 5a) and the measured variables (Fig. 5b). Only those variables which represent at least $20 \%$ of the axes variance are presented. The ordination of the sampling sites (Fig. 5a) does not show a clear separation between the lakes with exception of those lakes which form cluster VII and the isolated Lake Prokhladnoe PG1744. The ratio of the eigenvalues of axis 1 and axis 2 indicates that the variability of the physico-chemical characteristics of the studied lakes may be mainly driven by a strong gradient. The ordination of the variables (Fig. 5b) shows their interrelation. The comparison of the site scores with those of the constrained ordination (Fig. 6a) shows a significant positive correlation between them $(r=0.73)$. 
(a)

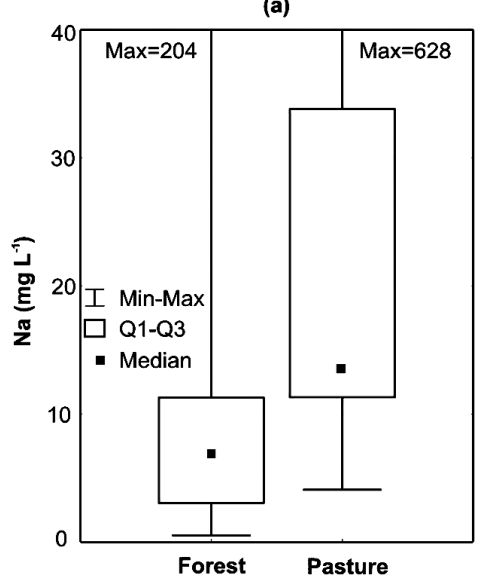

(c)

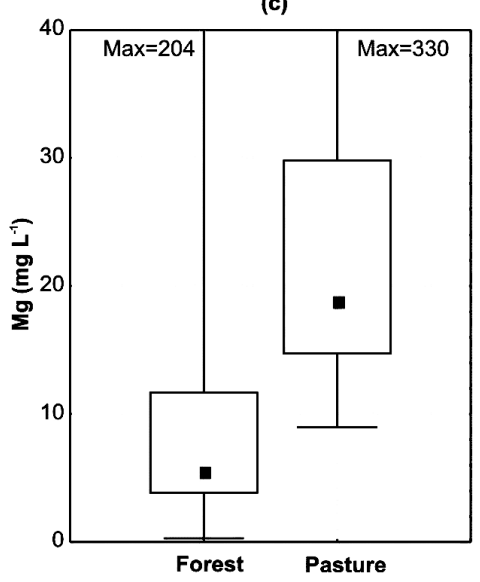

(b)

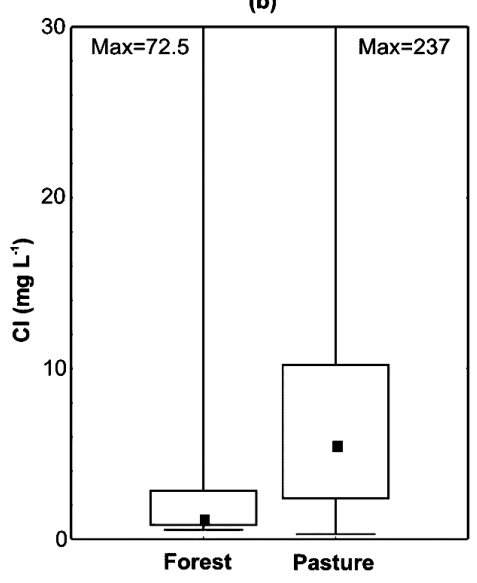

(d)

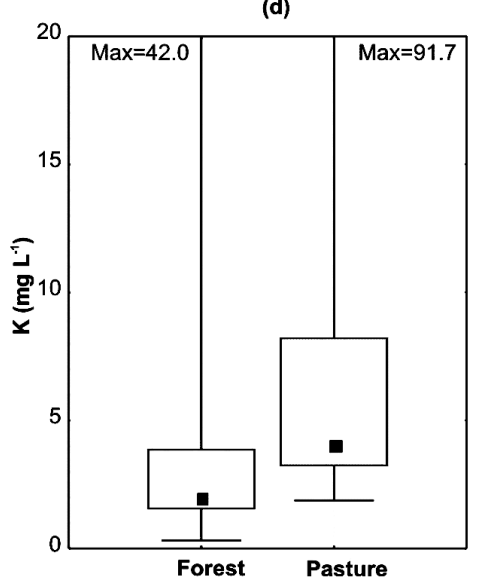

Fig. 4. Box-Whisker plots for selected physico-chemical characteristics of the lakes in Central Yakutia. The Box-Whisker plots are categorized according to the vegetation of the surroundings of the lakes.
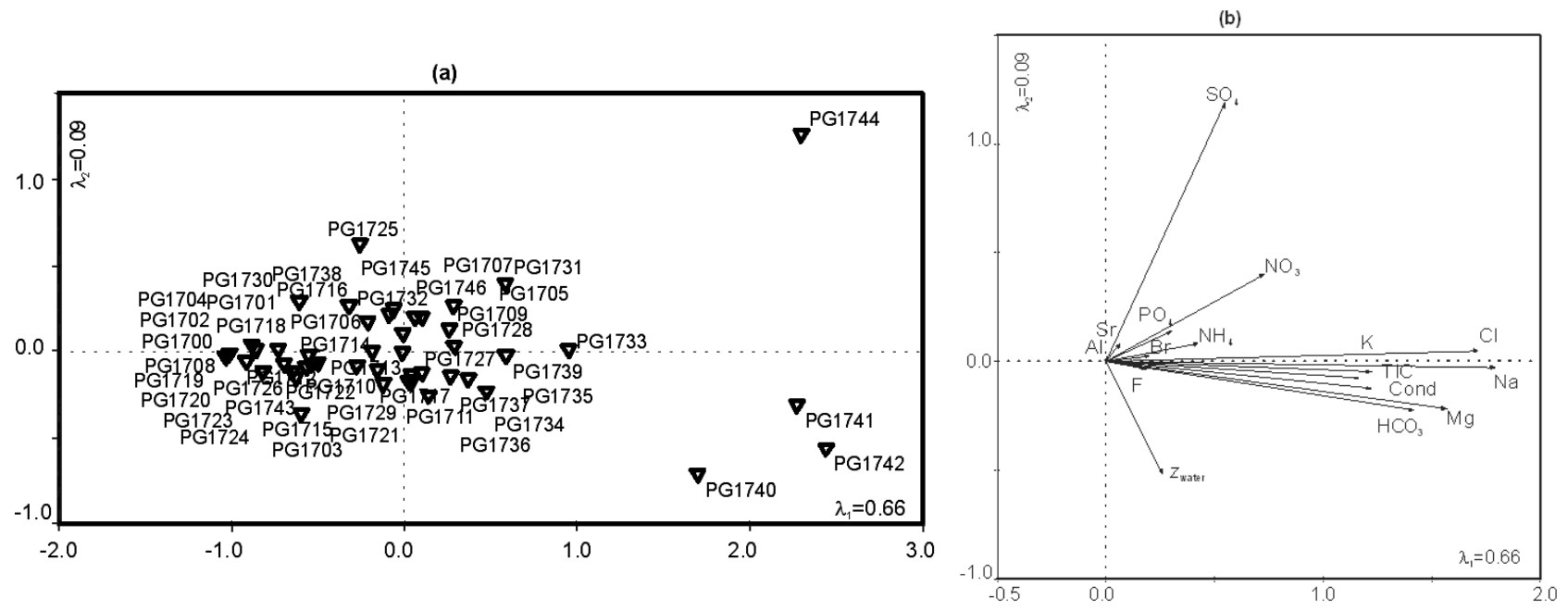

Fig. 5. Scatterplots of the principal components analysis of the measured physico-chemical characteristics. The upper scatterplot (a) represents the sampling sites of the first two ordination axes. The lower scatterplot (b) represents the physico-chemical variables which represent at least $20 \%$ of the variance of the ordination axes. 

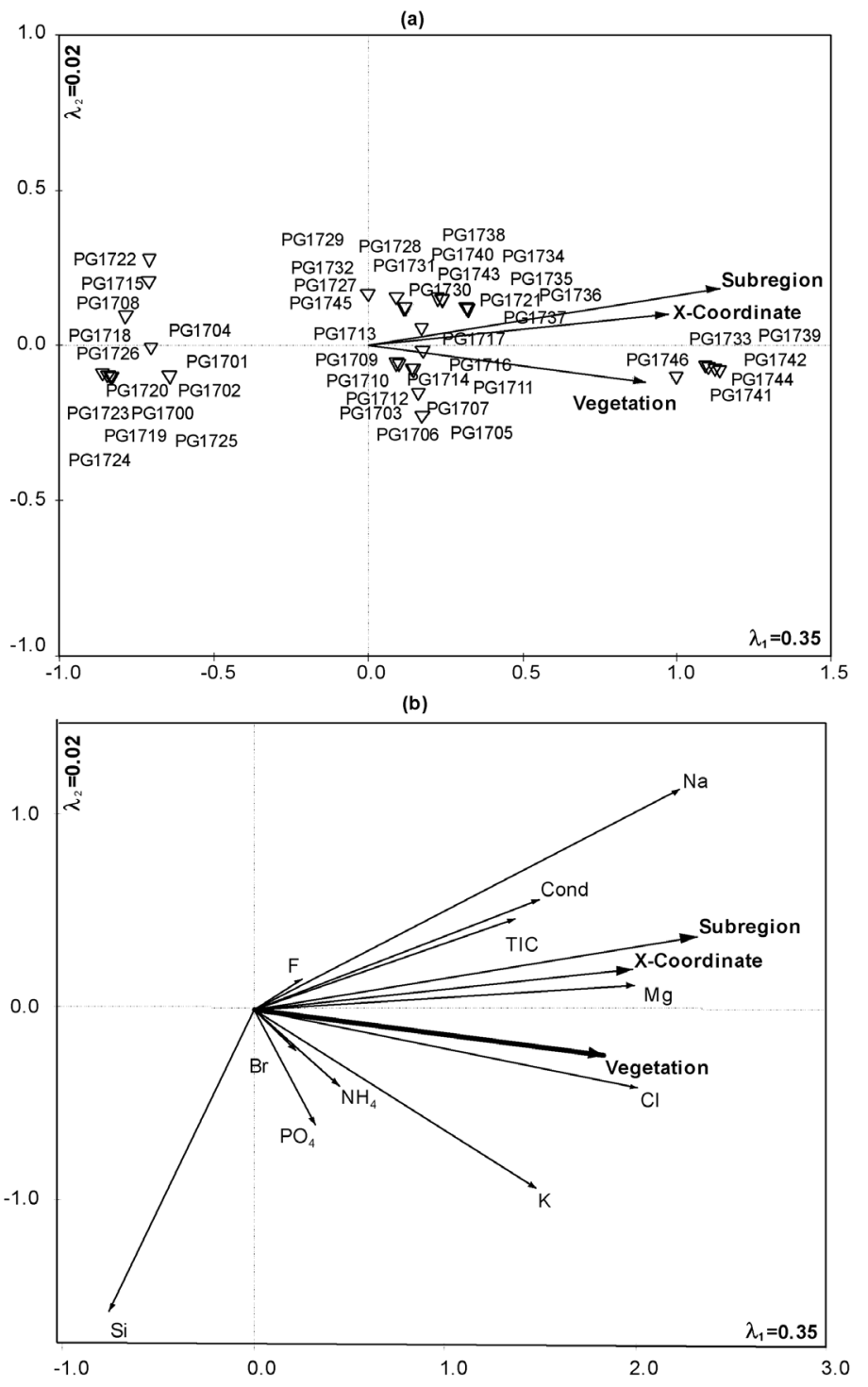

Fig. 6. Biplots of the redundancy analysis of physico-chemical characteristics and explanatory variables. The upper biplot (a) represents the sites and the significant explanatory variables of the first two canonical axes. The lower biplot (b) represents the physico-chemical characteristics and the explanatory variables. Only physico-chemical characteristics are shown which represent $20 \%$ of the variance of the canonical axes.

However, the constrained ordination results in more interpretable variation structure of the lakes. In figure 6, the sampling sites and the measured variables are shown alongside with the explanatory variables used in the analysis. The longer the vector of a variable, the larger its variance and its contribution to the canonical axes. From the RDA plot it is evident, that water chemistry characteristics such as $\mathrm{Na}, \mathrm{Cl}, \mathrm{Mg}, \mathrm{K}$, electrical conductivity and TIC contribute most to the first canonical axis which accounts for $35 \%$ of the total variance of the data (Fig. 6b). All these variables are closely related and determine the alkalinity and salinity of the lakes. The second and the third (not shown) canonical axes are associated with nutrients such as $\mathrm{PO}_{4}, \mathrm{NO}_{3}, \mathrm{NH}_{4}$ as well as Secchi depth. Although significant, both axes 2 and 3 combined represent only $2.5 \%$ of the data variance.
Using a forward selection procedure, the explanatory variables Vegetation, Subregion and X-coordinate were found to be significant $(p \leq 0.05)$ and account for $37.5 \%$ of the data variance (see Fig. 6). All canonical axes were tested to be significant at $p \leq 0.05$. Figure 6 a shows the ordination of the sampling sites for the first two canonical axes. The explanatory variables Vegetation, Subregion and X-coordinate contribute most to the first canonical axis. The sites are classified according to the significant variables: the highest positive scores on the first axis were calculated for the most eastern sites of subregion 10 which are surrounded by pasture. These sites had the highest concentrations in $\mathrm{Mg}, \mathrm{Na}, \mathrm{K}, \mathrm{Cl}$, TIC and electrical conductivity (Fig. 6b). The cluster of sites in the negative half of axis 1 represents the forest sites of the westernmost regions around Vilyuysk. These 
lakes were very low in ionic concentrations, electrical conductivities, but slightly higher in Si (Fig. 6b).

To determine the influence of the explanatory variables on the water chemistry characteristics alone without any partial effects, a series of partial RDA were performed. The major result from these analyses are that the variable Vegetation represents $11 \%$ of the variance without any joint effects of other variables, followed by the longitude $(7.6 \%)$ and Subregion $(2.8 \%)$. Thus, vegetation changes do explain the largest part of the variance of the water chemistry characteristics of Central Yakutian lakes. The spatial position along the longitude also represents a considerable amount of variance; a further partitioning into subregions contributes little in understanding the water chemical gradients of the study lakes.

To analyze further the relationships between spatial positions of the lakes and their water chemistry characteristics, a Manteltest was carried out and semivariances were calculated. The result of the Manteltest indicates a significant positive association between the water chemistry characteristics of the lakes and the spatial coordinates $(r=0.19 ; p \leq 0.01)$. This supports the results of the RDA in terms of the influence of the longitude (site location). Although there is an association between geographical coordinates and water chemistry characteristics, the variogram analysis revealed no clear spatial structuring and no spatial autocorrelation for the principal components. However, the calculated semivariances are larger between the lakes of the Vilyuysk and Yakutsk region than the semivariances within each group of lakes which is also evident from the ANOVA outlined in table 3 .

\section{DISCUSSION}

The physico-chemical characteristics of the study lakes in Central Yakutia are similar to those in other arctic and subarctic regions. In general, most of the lakes are small, shallow and were formed by thermokarst processes. All lakes are slightly alkaline to alkaline. This is typical for lakes in Central and Eastern Siberia (Duff et al. 1999; Laing et al. 1999; Laing \& Smol 2000). Most of the lakes are oligotrophic according to the classification of Vollenweider \& Kerekes (1982), which is a common characteristic of arctic and subarctic lakes (e.g. Duff et al. 1999; Hamilton et al. 2001; Lim et al. 2001; Michelutti et al. 2002a, b; Lim et al. 2005). However, similar to the study of Lim et al. (2005), we observed four hypertrophic lakes in the study area around Yakutsk. The nutrient-rich characteristics of lakes in this region are not surprising as these lakes are impacted by agricultural practices unlike the study area around Vilyuysk. Additionally, one of the study lakes (Lake Beydine, PG1733) was strongly affected by water birds contributing to its hypertrophic status. In the study region Vilyuysk, four eutrophic and five mesotrophic lakes were found, all located closely to villages and subjected to anthropogenic activities (e.g. swimming, domestic animals). The study of Lim et al. (2005), however, indicates that shallow lakes are especially subjected to wind-induced mixing of sediments and phosphate release from the sediments. Although not significant, there is a slight tendency that the transparency of the meso and eutrophic lakes, as measured by Secchi depth, in the Vilyuysk study region is reducing. Since poor transparency of the Central Yakutian lakes is most often caused by resuspension of sediments, enhanced phosphate concentrations could be influenced by phosphate release from the sediments.

The variability in the concentrations of major cations and anions, and related variables are strongly affected by the negative hydrological balance in the central part of Yakutia, together with land use intensity in the lakes' catchments. The median of the electrical conductivity is slightly higher than in comparable studies in Canada's High Arctic (e.g., Michelutti et al. 2002a, b; Lim et al. 2005). However, in comparison to lakes in northern Russia (Duff et al. 1999; Laing et al. 1999; Laing \& Smol, 2000; Solovieva et al. 2002, 2005), lakes in Central Yakutia have distinctly higher electrical conductivities, even though the sites of Duff et al. (1999) are located much closer to the Arctic Sea coast. The same holds true for sites in the Canadian High Arctic (e.g., Lim et al. 2005). This demonstrates that climatic setting (i.e., the continentality) together with anthropogenic effects strongly influence the physico-chemical characteristics of Central Yakutian lakes. This is quite apparent when we compare the electrical conductivity measurements from lakes studied by Duff et al. (1999) in the Lena Delta region (10 to $143 \mu \mathrm{S} \mathrm{cm}^{-1}$ ) with those from Central Yakutian lakes (60 to $3600 \mu \mathrm{S} \mathrm{cm}^{-1}$ ). In particular, in the region around Yakutsk (subregion 10), there are four lakes with conductivities of $>1800 \mu \mathrm{S}$ $\mathrm{cm}^{-1}$ (sites PG1740, PG1741, PG1742 and PG1744). This is the result of the negative water balance in Central Yakutia that decreases the water levels and as a consequence, the enrichment of soluble salts.

Our analysis has shown that ionic concentrations, TIC as well as electrical conductivities are significantly higher in Yakutsk than in Vilyuysk. The RDA has shown that vegetation and the longitude (i.e. the variable X-coordinate) are the controlling variables. It should be noted that the longitude is representative for the different climate setting in both study regions, since, according to Gavrilova (1973), the negative water balance in the region around Yakutsk is up to $25 \%$ higher than in the region around Vilyuysk. Thus, the higher ionic concentrations in the lakes around Yakutsk are also caused by the larger desiccation. The phenomenon of lakes affected by desiccation was observed in both study regions. Although not evident from our data, the lakes at the sites PG1703 to PG1706 formerly consisted of one single lake basin (Pestryakova, personal communication) which is still visible from their morphometric 
structure. This is the result of the regional moisture deficit which partitioned the former Lake Satagai (PG1706) into four different lakes since the first half of the last century.

The concentrations of $\mathrm{Cl}$ are in the range of values which are typically found in freshwater lakes (e.g., Lim et al. 2005) with four exceptions. These four lakes at the sites PG1740, PG1741, PG1742 and PG1744 are subjected to severe desiccation and as a result have anomalously high electrical conductivity values. The medians of the concentrations of major cations are in general comparable with studies from Arctic Canada (e.g., Hamilton et al. 2001; Lim et al. 2001) but higher than those from lakes in the Russian Arctic (Duff et al. 1999). The trend in the relative concentrations of major cations in the Central Yakutian lakes is $\mathrm{Ca}>\mathrm{Mg}>\mathrm{Na}>\mathrm{K}$ which corresponds to most of the studies in the Canadian High Arctic (Lim et al. 2001; Michelutti et al. 2002b), Canadian Subarctic (Pienitz et al. 1997; Rühland et al. 2003) and Arctic Russia (Duff et al. 1999). Similar to the coastal sites in the Canadian High Arctic (Lim et al. 2005), the order is shifted to $\mathrm{Na}>\mathrm{Mg}>\mathrm{K}>\mathrm{Ca}$ for the more saline lakes although the Central Yakutian lakes are not in the proximity of the coast (Fig. 1). It should be noted, that the lakes in the Canadian Subarctic and especially in the High Arctic are, opposite to the Central Yakutian lakes, isolated and not subjected to anthropogenic influence. However, it is surprising that the concentrations of $\mathrm{Ca}$ do not increase in these lakes. The $\mathrm{Na} / \mathrm{Ca}$ ratio (an indicator for saline conditions) is $<1.0$ at most of the sites, particularly in study region I and increases in study region II. There is a more than tenfold increase in $\mathrm{Na} / \mathrm{Ca}$ ratio in four of our study lakes (PG1740, PG1741, PG1742 and PG1744). However, ratios between 1.0 and 3.0 were also found at lakes with electrical conductivities between 400 and $600 \mu \mathrm{S} \mathrm{cm}^{-1}$. The $\mathrm{Na} / \mathrm{K}$ ratios were in the range between 1.0 and 13.0. These values are similar as reported in the studies on the lakes in the Canadian High Arctic (e.g., Hamilton et al. 2001; Lim et al. 2001; Michelutti et al. 2002a, b; Lim et al. 2005). The ratios found in the Central Yakutian lakes are significantly correlated to the vegetation in the catchment. Low ratios were observed at the forest sites and higher ratios at the pastured sites. Similarly, Lim et al. (2005) provided strong evidence that their ratios are dependent on the degree of lushness in catchment vegetation. The $\mathrm{Na} / \mathrm{K}$ ratios are highest in the more saline lakes. In the study of Lim et al. (2005), the highest ratios were observed in lakes closely located to the Sea coast. However, although there are similarities between the data of Lim et al. (2005) and our data, the Central Yakutian lakes are not isolated and in proximity of the coast. The controlling mechanisms for the physico-chemical characteristics of the Central Yakutian lakes are thus different.

In Central Yakutia, local vegetation and land use changes as well as different climate settings in both study regions (i.e., as reflected by higher evaporation in the region around Yakutsk) control the local limnological changes in the study lakes. The relationships between physico-chemical characteristics of lake water and their controlling factors can be used for climate studies and empirical model development in paleoenvironmental studies. Although evident, the human impact on the lakes does not affect their climate signal, but appropriate study lakes should be chosen carefully in order to carry out paleoenvironmental studies.

\section{CONCLUSIONS}

Statistical analyses of physico-chemical characteristics of 47 lakes in Central Yakutia were presented. The main goals of these analyses were to explore significant differences in the measured characteristics between the study lakes, to classify the lakes according to their limno-chemical properties and to find out possible gradients which explain the variability of the physicochemical properties. Investigations were carried out in two regions in the Central Yakutian lowlands. Most of the lakes were shallow, relatively small and had a considerably varying transparency. The measurements have shown that all lakes were slightly alkaline to alkaline. In general, most of the lakes can be classified as oligotrophic, nine lakes in the study region of Vilyuysk were mesotrophic to eutrophic and three lakes in the study region Yakutsk were hypertrophic.

A major part of the variability of measured physicochemical characteristics can be attributed to the concentrations of major ions and the electrical conductivity. Many of the variables differed significantly between both study regions and among lakes that are surrounded by forests and pasture. It is evident from our analysis, that the vegetation in the catchments and climate induced moisture deficit are the main controlling variables and represent a significant part of the variation in the physico-chemical characteristics of our study lakes. The measurements have shown higher potassium inputs into the lakes at more vegetated catchment areas. The spatial position of the lakes determines a small, but significant part in the variation of the measurements. Lakes in the study region Yakutsk are particularly subjected to the negative water balance in the continental areas of Central Yakutia. This is evident from exceptionally high concentrations of major cations, $\mathrm{Cl}$ and electrical conductivity as well as from the high $\mathrm{Na} / \mathrm{Cl}$ ratios. Four lakes in the study region of Yakutsk can be classified as slightly saline.

The exploratory analysis of the physico-chemical characteristics of Central Yakutian lakes has major implications for the limnological and paleoenvironmental research in these regions. Our results have shown that, besides differences in the catchment vegetation, climate related effects like the negative water balance in Central Yakutia are among the dominant 
factors for differences in the water chemistry of lakes. Our findings are of major importance for any further limnological assessments and serve as baseline data for long-term monitoring studies of water quality. The results of this study are also the basis for inference model development in order to reconstruct the paleoenvironments in Yakutia using biological indicators such as diatoms and chironomids.

\section{ACKNOWLEDGEMENTS}

The authors would like to thank M. Gerasimova, I. Nikolaev, K. Stachura-Suchoples, D. Subetto and all other participants of the expeditions during the summers 2003 and 2004 in Central Yakutia as well as A. Eulenburg and S. Heym for technical assistance. We are grateful to the Alexander von Humboldt Foundation which awarded a grant to L. Nazarova. We also would like to thank K. Rühland and E. Ito for improving earlier versions of the manuscript.

\section{REFERENCES}

Akademiya Nauk. 1989. Geocriology of USSR, Middle Siberia. Nauka, Moscow.

Andreev, A.A. \& V.A. Klimanov. 2000. Quantitative Holocene climatic reconstruction from Arctic Russia. J. Paleolimnol., 24: 81-91.

Anisomova, N.P. 1959. Chemical composition of underground and surface waters and some laws of its change in the area of Middle Lena River. Yakutsk.

Anisimova, N.P. 1973. Peculiarities of formation and distribution of salted waters in alluvial deposits of Central Yakutia. In: Questions of Yakutian Geography, Volume 6. Gidrometeoizdat, Leningrad: 97-103.

Anisimova, N.P. 1978. Hydrochemical investigations in permafrost sciences. In: Proceedings of the 3rd International Conference on Permafrost Sciences, Volume 1. Edmonton, Alberta, Canada: 488-494.

Anisimova, N.P., D.D. Savinov \& A.N. Kapitonov. 2005. Chemical composition of thermokarst lakes. In: Alas Ecosystem. Structure, functioning, dynamics. Nauka, Novosibirsk: $32-58$.

Antoniades, D., M.S.V. Douglas \& J.P. Smol. 2005. Quantitative estimates of recent environmental changes in the $\mathrm{Ca}$ nadian High Arctic inferred from diatoms in lake and pond sediments. J. Paleolimnol., 33: 349-360.

Bennion, H. \& M.A. Smith. 2000. Variability in the water chemistry of shallow ponds in southeast England, with special reference to the seasonality of nutrients and implications for modelling trophic status. Hydrobiologia, 436: 145-158.

Birks, H.J.B. 1995. Quantitative palaeoenvironmental reconstructions. In: D. Maddy \& J.S. Brew (Eds.), Statistical Modelling of Quaternary Science Data, Technical Guide, 5th Edition. Quaternary Science Association, Cambridge: 161-254.

Birks, H.J.B. 1998. Numerical tools in palaeolimnology - Progress, potentialities, and problems. J. Paleolimnol., 20: 307-332.

Carpenter, S.R., S.G. Fisher, N.B. Grimm \& J.F. Kitchell. 1992. Global change and freshwater ecosystems. Ann. Rev. Ecol. Syst., 23: 119-139.

Duff, K., T.E. Laing, J.P. Smol \& D.R.S. Lean. 1999. Limnological characteristics of lakes located across arctic treeline in northern Russia. Hydrobiologia, 391: 205-222.
Englund, E. \& E. Sparks. 1991. GEO-EAS 1.2.1. Geostatistical Environmental Assessment Software - User's guide. US Environmental Protection Agency, Las Vegas: $186 \mathrm{pp}$.

Findlay, D.L., S.E.M. Kasian, M.P. Stainton, K. Beaty \& M. Lyng. 2001. Climatic influences on algal populations of boreal forest lakes in the Experimental Lakes Area. Limnol. Oceanogr., 46: 1784-1793.

Fischer, H., T. Kumke, G. Lohmann, G. Flöser, H. Miller, H. von Storch \& J.F.W. Negendank. 2004. The Climate in Historical Times - Towards a synthesis of paleoclimate variability using proxy data and climate models. Springer Verlag, Berlin: $487 \mathrm{pp}$.

Gavrilova, M.K. 1973. Climate of Central Yakutia. Akademiya Nauk, SSSR. Institut Merzlotovedeniya, Yakutsk.

Hamilton, P.B., K. Gajewski, D.E. Atkinson, \& D.R.S. Lean. 2001. Physical and chemical limnology of 204 lakes from the Canadian Arctic Archipelago. Hydrobiologia, 457: 133-148.

Houghton, J.T., L.G. Meira Filho, B.A. Callander, N. Harris, A. Kattenberg \& K. Maskell. 1996. Climate Change 1995 - The Science of Climate Change. Cambridge University Press, Cambridge: $572 \mathrm{pp}$.

Korhola, A., M. Tikkanen \& J. Weckström. 2005. Quantification of Holocene lake-level changes in Finnish Lapland using a Cladocera-lake depth transfer model. J. Paleolimnol., 34: 175-190.

Ksenofontova, M., T. Kumke, L. Pestryakova \& H.-W. Hubberten. 2005. Limnological characteristics of lakes in Central Yakutia. In: Deutsche Gesellschaft für Limnologie (Eds), Jahrestagung der Deutschen Gesellschaft für Limnologie - Tagungsbericht 2004. Weißensee Verlag, Berlin: 151-155.

Kumke, T., C. Schölzel \& A. Hense. 2004. Transfer functions for paleoclimate reconstructions - Theory and Methods. In: H. Fischer, T. Kumke, G. Lohmann, G. Flöser, H. Miller, H. von Storch \& J.F.W. Negendank (Eds), The Climate in Historical Times - Towards a synthesis of paleoclimate variability using proxy data and climate models, Springer Verlag, Berlin: 229-244.

Kumke, T., A. Schoonderwaldt \& U. Kienel. 2005. Spatial variability of sedimentological properties in a large Siberian lake - Methods and implications. Aquat. Sci., 67: 86-96.

Laing, T.E., R. Pienitz \& J.P. Smol. 1999. Freshwater diatom assemblages from 23 lakes near Norilsk, Siberia: A comparison with assemblages from other circumpolar treeline regions. Diat. Res., 14: 285-305.

Laing, T.E. \& J.P. Smol. 2000. Factors influencing diatom distributions in circumpolar treeline lakes in Northern Russia. J. Phycol., 36: 1035-1048.

Legendre, P. \& L. Legendre. 1998. Numerical Ecology, 2nd Edition. Elsevier, Amsterdam: 853 pp.

Lim, D. S.S., M.S.V. Douglas, J.P. Smol \& D.R.S. Lean. 2001. Physical and chemical limnological characteristics of 38 lakes and ponds on Bathurst Island, Nunavut, Canadian High Arctic. Int. Rev. Hydrobiol., 86: 1-22.

Lim, D.S.S., M.S.V. Douglas \& J.P. Smol. 2005. Limnology of 46 lakes and ponds on Banks Island, N.W.T., Canadian Arctic Archipelago. Hydrobiologia, 545: 11-32.

McCune, B. \& M.J. Mefford. 1999. PC-ORD. Multivariate Analysis of Ecological Data, Version 4. MjM Software Design, Gleneden Beach: 237 pp.

Michelutti, N., M.S.V. Douglas, D.R.S. Lean \& J.P. Smol. 2002a. Physical and chemical limnology of 34 ultraoligotrophic lakes and ponds near Wynniatt Bay, Victoria Island, Arctic Canada. Hydrobiologia, 482: 1-13.

Michelutti, N., M.S.V. Douglas, D.C.G. Muir, X. Wang \& J.P. Smol. 2002b. Limnological characteristics of 38 lakes and ponds on Axel Heiberg Island, High Arctic Canada. Int. Rev. Hydrobiol., 87: 385-399. 
Pewe, T.L. \& A. Journaux. 1983. Origin and character of loesslike silt in unglaciated south-central Yakutia, Siberia, USSR. US Geological Survey Professional Paper no. 1262. US Government Printing Office, Washington.

Pienitz, R., J.P. Smol \& D.R.S. Lean. 1997. Physical and chemical limnology of 59 lakes located between the southern Yukon and the Tuktoyaktuk Peninsula, Northwest Territories (Canada). Can. J. Fish. Aquat. Sci., 54: 330-346.

Regier, H.A., J.A. Holmes \& D. Pauly. 1990. Influence of temperature changes on aquatic ecosystems: an interpretation of empirical data. Trans. Am. Fish. Soc., 119: 374389.

Rühland, K.M. \& J.P. Smol. 1998. Limnological characteristics of 70 lakes spanning arctic tree line from Coronation Gulf to Great Slave Lake in the Central Northwest territories, Canada. Int. Rev. Hydrobiol., 83: 183-203.

Rühland, K.M., J.P. Smol, X. Wang \& D.C.G. Muir. 2003. Limnological characteristics of 56 lakes in the Central Canadian Arctic Treeline. J. Limnol., 62: 9-27.

Schindler, D.W., S.E. Bayley, B.R. Parker, K.G. Beaty, D.R. Cruickshank, E.J. Fee, E.U. Schindler \& M.P. Stainton. 1996. The effects of climate warming on the properties of boreal lakes and streams at the Experimental Lakes Area, northwestern Ontario. Limnol. Oceanogr., 41: 1004-1017.

Smol, J.P. 2002. Pollution of Lakes and Rivers - A Paleoenvironmental Perspective. Arnold Publishers, London: $280 \mathrm{pp}$.

Sokal, R. \& F. Rohlf. 1995. Biometry. 3rd edition. W. H. Freeman, New York: 859 pp.

Solovieva, N., V.J. Jones, P.G. Appleby \& B.M. Kondratenok. 2002. Extent, environmental impact and long-term trends in atmospheric contamination in the Usa basin of East-
European Russian Arctic. Wat. Air Soil Pollut., 139: 237260.

Solovieva, N., V.J. Jones, L. Nazarova, S.J. Brooks, H.J.B. Birks, J.-A. Grytnes, P.G. Appleby, T. Kauppila, B. Kondratenok, I. Renberg \& V. Ponomarev. 2005. Palaeolimnological evidence for recent climatic change in lakes from the Northern Urals, arctic Russia. J. Paleolimnol., 33: 463-482.

StatSoft, Inc. 1999. Statistica for Windows. StatSoft, Inc., Tulsa.

Tahtadzhan, A.L. 1978. Floristic areas of the world. Nauka, Leningrad.

ter Braak, C.J.F. \& P. Šmilauer. 2002. CANOCO Reference Manual and CanoDraw for Windows User's guide: Software for Canonical Community Ordination (version 4.5). Microcomputer Power, Ithaka: $500 \mathrm{pp}$.

Vollenweider, R.A. \& J. Kerekes. 1982. Eutrophication of Waters. Monitoring, Assessment and Control. Organization for Economic Co-Operation and Development (OECD), Paris: 156 pp.

Watson, R.T. \& D.L. Albritton. 2001. Climate Change 2001: Synthesis Report. Cambridge University Press, Cambridge: $397 \mathrm{pp}$.

Webster, R. \& M.A. Oliver. 2000. Geostatistics for Environmental Scientists. Wiley, Chichester: $271 \mathrm{pp}$.

Wetzel, R.G. \& G.E. Likens. 1991. Limnological Analyses, 2nd edition. Springer Verlag, Berlin: $391 \mathrm{pp}$.

Wolin, J. \& H. Duthie. 1999. Diatoms as indicators of water level change in freshwater lakes. In: E. Stoermer \& J.P. Smol (Eds), The Diatoms - Applications for the Environmental and Earth Sciences. Cambridge University Press, Cambridge: 183-202. 